\section{The Mosquitoes of Uganda}

In the Bulletin of Entomological Research (36, Pt. 1 ; 1945), A. J. Haddow of the Yellow Fever Research Institute, Entebbe, discusses the mosquitoes of the Bwamba country, Uganda. The work has special reference to a single species-Aëdes (Stegomyia) simpsoni Thea.- - which appears to be the main carrier of the virus of yellow fever among human beings in the territory just mentioned. Ecological studies showed that forest was cooler and moister by day than a banana plantation, while the latter was cooler and moister than the open air. At night, however, the climate of all three environments was strikingly similar. Experimental catches made over 24-hour periods and large-scale routine catches were carried out. As the result it appeared that Aëdes simpsoni bites mainly in coffee gardens, maize fields and in the thinner parts and fringes of banana plantations. It is scarce in exposed situations and prefers the blood of man to that of goats, fowls or monkeys. It is demonstrated that many forest mosquitoes occur in banana plantations. Analysis of day and night catches seems to point to their migrating into plantations, from the forest, at night time. The results of catches in forest and banana plantations show that there are two types of biting cycle. In one there are two main peaks of activity in twentyfour hours, usually about sunrise and sunset. In the other there is a single peak of activity in twenty-four hours which may occur by day or by night. It is suggested that these cycles are dependent on features of the microclimate, and the findings are believed to have a bearing upon yellow fever epidemiology.

\section{The National Trust: Annual Report, 1944-45}

THE annual report for $1944-45$ of the National Trust contains a list of properties owned or protected by the Trust. The mode of acquirement (or nature of control), acreage and history are briefly noted under each property heading. This list is both timely and useful; but it would have been of greater use for reference purposes had the sites been classified under county headings. As it stands, a person unacquainted with local names will have to examine sixty-eight pages before he can discover what properties the Trust owns or controls in, say, Cornwall. The index at the end of the list is no more helpful in this respect. The report preceding the property list summarizes work and development during the past fifty years. Fow will read it without feeling gratitude towards the Trust and the large number of public-spirited donors whose work and generosity have made possible the preservation of so many places of historic interest and natural beauty in Britain for the cultural and recreational enjoyment of the nation.

\section{Regional Research Station in N.S.W.}

To facilitate study of problems associated with the development of irrigated pastures and forage crops on the heavy grey and red-brown soils of the Riverina district of New South Wales, Messrs. F. S. Falkiner and Son have presented 1,550 acres of typical country to the Australian Council for Scientific and Industrial Research. An experimental farm will be established, with laboratory facilities, some twelve miles away in the town of Deniliquin. Water will be provided by the State Water Conservation and Irrigation Commission. It is hoped to deal there with many of the plant and animal production problems affecting one of the most important agricultural areas of the Commonwealth.

\section{Announcements}

The Gold Medal of the Royal Astronomical Society has been awarded to Prof. Jan H. Oort, director of the Leyden Observatory, for his investigation of the dynamics and rotation of the galactic system. A Jackson-Gwilt Medal and Gift has been awarded to Mr. H. W. Newton, of the Royal Observatory, Greenwich, for his work on the sun, notably on the relation between solar flares and magnetic storms.

Dr. E. B. Worthington, director of the Freshwater Biological Association's station on Lake Windermere, has been appointed joint secretary to the Colonial Research Committee. It is intended that Dr. Worthington should be available for extensive travel in the Colonies and assistance to colonial authorities in matters of research, and it is expected that he will go to East Africa soon for this purpose.

DR. H. S. Holden, director of the East Midland Forensic Science Laboratory, Nottingham (formerly professor of botany in University College, Nottingham), has been appointed to succeed Dr. J. Davidson as director of the Metropolitan Police Laboratory on April 1.

Ballor College, Oxford, is making an election, not later than October 1946, to a research fellowship of the annual value of $£ 300$ without restriction as to subject. Candidates must have taken a degree at Oxford or at some other university. The tenure of the fellowship does not necessarily exclude the holding of some other post approved of by the College, and will in the first instance be for three years, with the possibility of re-election. Further details may be obtained from the Secretary, Balliol College, Oxford. Applications must be received by May 1.

IT is hoped to make this year a limited number of appointments to Commonwealth Fund Fellowships tenable in the United States. Before the War, there were three categories of the fellowships, namely, ordinary, Service (for British Government servants overseas) and home Civil Service (for Civil servants in Britain), but only ordinary fellowships are to be awarded in 1946. Candidates must be of British descent, university graduates, and less than thirty. five years old ; no women will be considered. Applica. tions must reach the secretary of the committee of award, Mr. Richard H. Simpson, Commonwealth Fund Fellowships, 35 Portman Square, London, W.1, by February 28.

The Clough Memorial Research Fund of the Edinburgh Geological Society was instituted in 1935 for the purpose of encouraging geological research in Scotland and the north of England (the latter being defined as the counties of Northumberland, Durham, Cumberland, Westmorland and Yorkshire). Approximately $£ 30$ is available annually. Applications for grants are invited for the period April 1, 1946-March 31, 1947; they must be in the hands of the Secretary, Clough Memorial Research Fund Committee, Edinburgh Geological Society, Synod Hall, Castle Terrace, Edinburgh, not later than March 1.

Prof. H. S. CARsLaw asks us to state that he has prepared, in association with Dr. J. C. Jaeger, a new work based on, but superseding, his "Introduction to the Mathematical Theory of the Conduction of Heat in Solids". He therefore regrets the appearance of a reprint of his older book recently announced by Dover Publications, permission for which was given before he was consulted. 